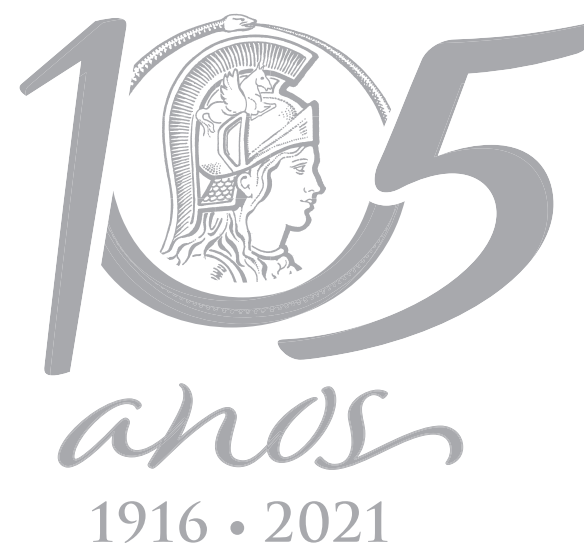

\title{
ECOSYSTEMS
}

\section{Trophic relationships and use of area of two sympatric small cetaceans in the Southwestern Atlantic Ocean determined by carbon and nitrogen stable isotopes}

\author{
LAURA B. CAMPOS \& MARCOS CÉSAR DE O. SANTOS
}

\begin{abstract}
As cetaceans are sentinels of the marine environment, studying their life history is of utmost importance in understanding their habits and their interaction with the environment. To achieve this goal, it is important to study their ecological niches through the investigation of their habitat use patterns and trophic relationships. This study aimed to evaluate if there are differences in the habitat use patterns and the trophic ecology of franciscana (Pontoporia blainvillei) and Guiana dolphins (Sotalia guianensis) accidentally caught off the south coast of São Paulo State, and Guiana dolphins biopsied in the Cananeia estuary, southeastern Brazil, based on the carbon and the nitrogen stable isotopes analysis. Isotopic ratios were estimated from skin samples. The isotopic niche size and overlap were calculated using the SIBER package ( $R$ software). The gathered results showed evidence of spatial segregation between Guiana dolphins and franciscanas. The Guiana dolphins sampled inside and outside the estuary showed evidence of trophic and spatial segregation. No difference in isotopic values between sexes was found for both species. Such differences between franciscanas and Guiana dolphins were expected as both species have distinct life histories as a result of different evolutionary pathways.
\end{abstract}

Key words: isotopic niche, Pontoporia blainvillei, Sotalia guianensis, Southwest Atlantic, stable isotopes, use of area.

\section{INTRODUCTION}

As cetaceans are sentinels of the marine environment (Moore 2008), studying their life history is of utmost importance in understanding their habits and their interaction with the environment (Taylor 1924). One of the tools to better understand their ecological roles is to study their ecological niches by investigating area usage and trophic relationships.

The ecological niche is the set of biotic and abiotic conditions under which a species can survive by maintaining stable population sizes (Hutchinson 1957). The niche can be composed of several dimensions: trophic (used resources), spatial (habitat in which they live and feed), and temporal dimension (range from a daytime activity pattern to annual migrations). Thus, niche differentiation between sympatric species can occur from trophic, spatial, or temporal segregation to avoid competitive exclusion (Gause 2003, Hutchinson 1957, Pianka 1974). Resource and habitat partitioning may also occur in an intraspecific way, such as when it is related to sex classes, size classes, or age classes (Schoener 1974).

The most widely used tools for the study of the distribution, habitat use and feeding ecology in cetaceans are aerial or on-board surveys 
followed by systematically planned transects (Forcada 2018) and the analysis of stomach contents of stranded animals or accidentally caught in fishing operations (Trites \& Spitz 2018). Although stomach content analysis provides an important insight on cetacean feeding habits, the use of additional tools to investigate trophic ecology has been highlighting several known drawbacks of the above-reported technique.

Stable carbon and nitrogen isotope analysis is one of the alternatives which has been used to better understand the feeding ecology and habitat use of cetaceans (see Newsome et al. 2010). This tool reflects an integration of all prey assimilated into the predator tissue over time (Abend \& Smith 1997, Kiszka et al. 2010), while the use of stomach contents encompasses biases related to fast prey digestion, instantaneous representation of feeding habits, and inability to compare prey groups (Fitch \& Brownell 1968, Clarke 1986).

The isotopic composition of an organism is determined from the isotopic composition of everything that is ingested and absorbed by it (Newsome et al. 2010). Thus the isotopic ratio $\left(\delta^{13} \mathrm{C}\right.$ and $\delta^{15} \mathrm{~N}$ ) of consumers reflects those of their prey, with small retention of heavier isotopes and excretion of lighter isotopes (isotopic fractionation), resulting in enrichment at each trophic level (DeNiro \& Epstein 1978, 1981). The carbon isotope presents a conservative transfer of its isotopic relationships and results in low trophic enrichment (1-2\%), so the $\delta^{13} \mathrm{C}$ values are generally associated with the source of food resources and are used to trace the primary source of carbon in the food web (terrestrial $x$ marine; coastal $x$ oceanic; pelagic $x$ demersal) (DeNiro \& Epstein 1978). Nitrogen stable isotope ratio, on the other hand, does not exhibit such a conservative transfer, resulting in greater trophic enrichment (2-5 \%o) (Minagawa \& Wada 1984). The $\delta^{15} \mathrm{~N}$ values are associated with the trophic position occupied by the organism and are therefore used to study the trophic relationships in food webs and to evaluate trophic levels (DeNiro \& Epstein 1981).

In addition to the isotopic fractionation, it is important to know the turnover rate (i.e. time that the isotopic value of the sources takes to reflect on the consumer) of the analyzed tissue (Newsome et al. 2010). Each tissue has a different metabolic rate, resulting in a different turnover rate and providing dietary information at different time scales (Hobson et al. 1996, Kelly 2000). Turnover rates for franciscanas and Guiana dolphins' tissues have not been evaluated by any study yet. However, this rate has already been calculated for some odontocete species skin such as the beluga (Delphinapterus leucas; Aubin et al. 1990) and the bottlenose dolphin (Tursiops truncatus; Giménez et al. 2016) as being approximately two months.

The life histories of small toothed whales that inhabit the Brazilian coast, despite being increasingly studied, are still poorly known and, therefore, there is still a huge gap for further studies.

The franciscana dolphin, Pontoporia blainvillei (Gervais \& d'Orbigny 1844), and the Guiana dolphin, Sotalia guianensis (Van Bénéden 1864) are sympatric species of coastal and two estuarine basins in the southeastern coast of Brazil (Bordino et al. 2002, Silva et al. 2010). Along this area of distribution, their stocks have been facing severe population declines provoked by human activities (Ott et al. 2002, Crespo et al. 2010). As a consequence, the franciscana dolphin is categorized as "vulnerable" (Zerbini et al. 2017) and the Guiana dolphin as "near threatened" (Secchi et al. 2018) by the IUCN ("International Union for Conservation of Nature"). Therefore, investigations on several aspects of their life history and ecological traits 
are deemed necessary to better understand how management plans should be driven.

The southern coast of São Paulo state, in southeastern Brazil, hosts two resident populations of Guiana and franciscana dolphins. Guiana dolphins are found in both estuarine and coastal waters (Santos et al. 2019), meanwhile franciscanas are just found in local coastal waters (Santos et al. 2007). Recent investigations showed that several identified Guiana dolphins move from the local estuarine basin, known as the Cananeia estuary, to shallow coastal waters; and even from an estuarine basin to another, placed ca. $70 \mathrm{~km}$ southwards known as the Paranaguá estuarine complex (Santos et al. 2019). In two beaches placed at the entrance of the Cananeia estuary, just 11 individuals of the local population display a unique hunting behavior known as "beach hunting" (see Santos et al. 2010). It is a behavior that has been shared through generations of female dolphins and still calls the attention of investigators as these individuals may present a distinct strategy on using local waters when compared to the whole resident population. Cryptic to the environment and with a relatively smaller size, franciscanas are not easily sighted in local coastal murky waters. Therefore, the access to these individuals had come from investigations on stranded and/ or incidentally captured individuals.

Studies carried out with Guiana dolphins and franciscanas throughout their distribution, with stranded and bycaught animals, have shown that both are op portunistic and generalist feeders, but the Guiana dolphin showed specialist behavior in some regions (Rodríguez et al. 2002, Daura-Jorge et al. 2011, Pansard et al. 2011, Cremer et al. 2012). On the southeastern and southern coast of Brazil, their diet is composed primarily of demersal or benthopelagic fish, cephalopods, and crustaceans (Di Beneditto \& Siciliano 2007, Lopes et al. 2012, Henning et al.
2018). Franciscanas feed on juveniles or smallsized prey, usually up to $15 \mathrm{~cm}$ (Di Beneditto \& Ramos 2001), and Guiana dolphins consume prey with a greater variation in size, reaching up to $100 \mathrm{~cm}$ in length (Santos et al. 2002). Previous studies have shown differences among several feeding items consumed by local franciscana and Guiana dolphins (Lopes et al. 2012, Campos et al. 2020), as well as distinct main preys when comparing the feeding habits of Guiana dolphins found dead inner estuarine waters and the ones found along the shoreline (Lopes et al. 2012).

Based on the described scenario, the present study aimed to describe characteristics of area usage and trophic ecology of franciscana and Guiana dolphins found on the southern coast of São Paulo State using stable carbon and nitrogen isotope analysis.

\section{MATERIALS AND METHODS}

\section{Ethics}

All the experimental procedures were approved by the Ethics Committee on the Use of Animals of the Instituto Oceanográfico da Universidade de São Paulo (CEUA/IOUSP - Protocol Nº 009-Pesq).

\section{Study area}

This study was conducted along the southern coast of the São Paulo State and inland waters of the Cananeia estuary (24 $40^{\prime}$ S to $25^{\circ} 15^{\prime}$ 's) (e.g. Figure 1).

\section{Sample collection}

Skin samples of Guiana and franciscana dolphins were collected between 2011 and 2018 in both coastal and estuarine waters. Part of the samples analyzed was obtained from incidentally captured dolphins by the gillnet fleet which operates from the Cananeia port. A total of 11 franciscana dolphins (five males and six females) and 12 Guiana dolphins (six males and 


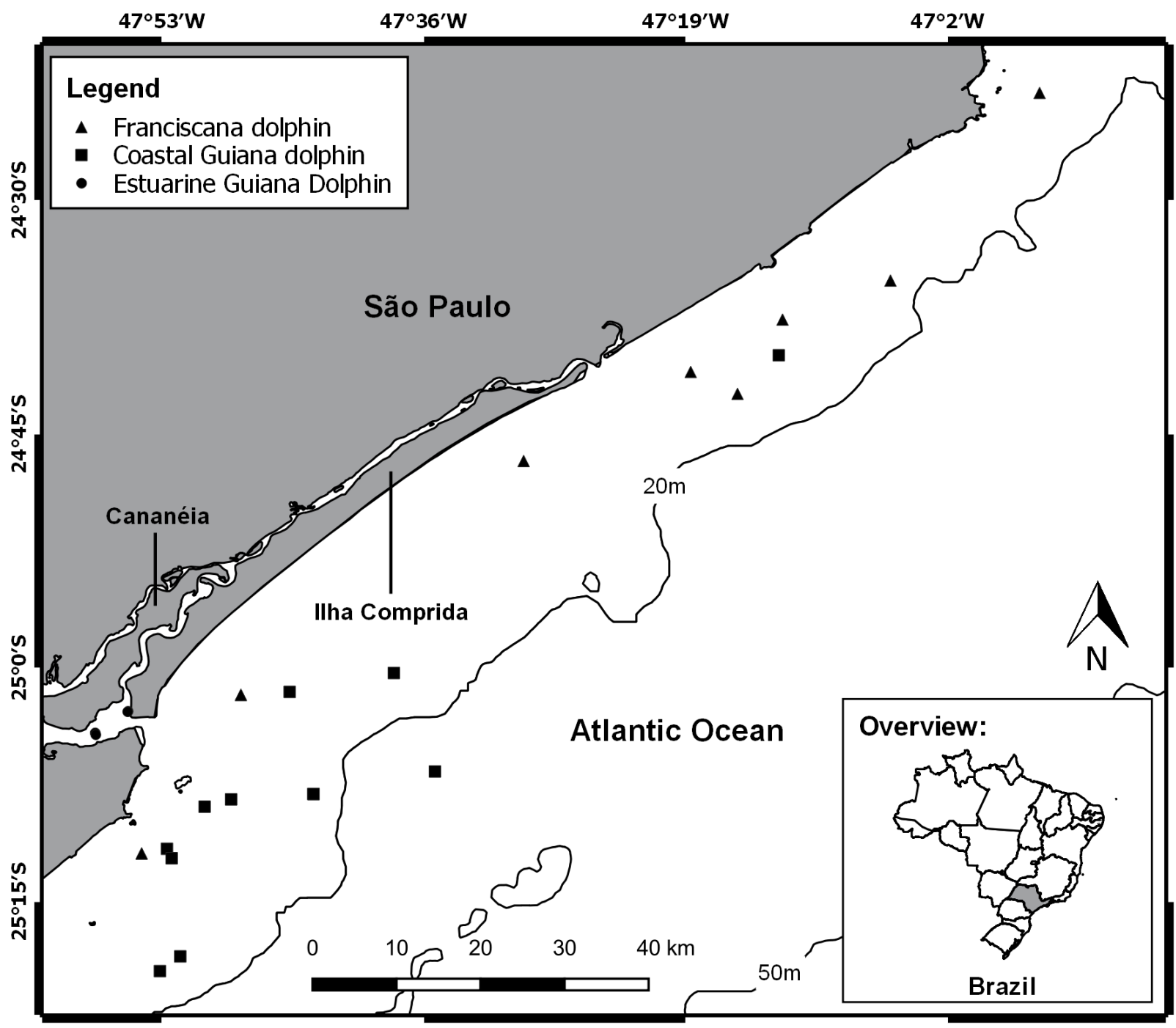

Figure 1. Map of the study area showing the southern coastal region of São Paulo state, southeastern Brazil. Dots indicate the exact locations where dolphins were sampled.

six females) were used (Table I). The remaining samples came from four biopsies collected from Guiana dolphins using a 120 lbs crossbow in inner estuarine waters between March and May 2018. One of these biopsies belonged to a beach hunter dolphin (Table I).

\section{Sample preparation and analysis}

Samples were kept in an oven at $60^{\circ} \mathrm{C}$ for $48 \mathrm{~h}$ or until completely dry, then they were grounded to a fine powder and weighed on a precision analytical balance. Isotopic concentrations of $\mathrm{C}$ and $\mathrm{N}$ were obtained from the Stable Isotope Core Laboratory at Washington State University (WSU) using an elementary analyzer (Costech) connected to a continuous flow Isotope Ratio Mass Spectrometry (IRMS) (Micromass Isoprai). The internationally accepted standards used were the VPDB (Vienna Pee Dee Belemnite) for carbon and atmospheric air for nitrogen.

The elemental composition of $\mathrm{C}$ and $\mathrm{N}$ was used to calculate the sample C:N ratio, which was used in the lipid mathematical correction in order to adjust the potential influence 
Table I. Sample size (n), mean values \pm standard deviation of $\delta^{13} \mathrm{C}$ and $\delta^{15} \mathrm{~N}$ and ellipse area (SEAc) for sampled Guiana (Sotalia guianensis) and franciscana (Pontoporia blainvillei) dolphins in Southeastern Brazil from 2011 to 2018.

\begin{tabular}{|c|c|c|c|c|}
\hline Species / Sex & $\mathbf{n}$ & $\delta^{13} \mathrm{C}(\% \circ)$ & $\delta^{15} N(\% \circ)$ & $\operatorname{SEAC}\left(\% \circ^{2}\right)$ \\
\hline P. blainvillei coast & 11 & $-15.6 \pm 0.2$ & $14.0 \pm 0.6$ & 0.35 \\
\hline Male & 5 & $-15.7 \pm 0.1$ & $13.9 \pm 0.5$ & 0.17 \\
\hline Female & 6 & $-15.6 \pm 0.2$ & $14.1 \pm 0.8$ & 0.51 \\
\hline S. guianensis coast & 12 & $-15.9 \pm 0.2$ & $13.9 \pm 0.3$ & 0.20 \\
\hline Male & 6 & $-15.9 \pm 0.2$ & $13.7 \pm 0.2$ & 0.19 \\
\hline Female & 6 & $-15.8 \pm 0.1$ & $14.0 \pm 0.4$ & 0.21 \\
\hline S. guianensis estuary & 3 & $-15.6 \pm 0.2$ & $12.0 \pm 0.1$ & - \\
\hline Beach hunter & 1 & -13.9 & 11.3 & - \\
\hline
\end{tabular}

from lipids (see Tieszen et al. 1983, Pinnegar \& Polunin 1999). The equations suggested by McConnaughey \& McRoy (1979) and modified for cetacean skins by Lesage et al. (2010) were used. Only values with a C:N ratio > 3.5 were corrected.

\section{Data analysis}

Normality and homogeneity of variance of the $\delta^{13} \mathrm{C}$ and $\delta^{15} \mathrm{~N}$ data were tested using the ShapiroWilk and Bartlett tests, respectively. A Student t-test (t) or Wilcoxon-Mann-Whitney (W) test was performed to evaluate whether the mean $\delta^{13} \mathrm{C}$ and $\delta^{15} \mathrm{~N}$ values differed significantly between franciscana and coastal Guiana dolphins, between Guiana dolphins sampled inside and outside the estuary, and subsequently between males and females of both species. All statistical analyzes were performed using the software " $\mathrm{R}$ " version 3.5.3 (R Core Team 2018).

Isotopic niches were explored using the $\mathrm{R}$ Stable Isotope Bayesian Ellipses (SIBER) method which uses standard ellipses to define the space that an animal population occupies in a bivariate isotopic space (Jackson et al. 2011), better known as the isotopic niche (Newsome et al. 2007). Further information can be extracted about animal ecology from the size and position of the ellipses. In addition, overlapping ellipses of different populations may indicate that they are exploiting the same food and/or habitat resource. SIBER version 2.1.4 was run in the $R$ 3.5.3 statistical environment (R Core Team 2018).

Three sets of ellipses were constructed using the data of $\delta^{13} \mathrm{C}$ and $\delta^{15} \mathrm{~N}$; one with the franciscana and coastal Guiana dolphins, one with franciscanas' males and females, and the other with Guiana dolphins' males and females. To estimate the standard ellipse's area (SEA) (sized to cover $40 \%$ of the data) the SEAc correction for small sample sizes was used (Jackson et al. 2011). The SEAc for each group was also used to calculate the isotopic niche overlap as an indication of similarity in food ecology (Jackson et al. 2011). The isotopic niche overlap was calculated in three different ways: the percentage of the overlapped area of one 
ellipse over another (i.e. franciscana over the Guiana dolphin and Guiana dolphin over the franciscana) and the percentage of the total niche space that is shared. The overlap ranges from 0 to $100 \%$, representing the overlap fraction between the SEAc of two groups.

Additionally, Bayesian modeling (SEAb) was used to estimate the area of ellipses. SEAb provides a range of results instead of a single value, taking into account data variability more robustly, thus enabling the calculation of error estimates and pairwise comparisons (Jackson et al. 2011). The SEAb was computed based on $10^{6}$ posterior draws, to test the probability that two isotopic niche areas differ from each other (proportion of standard ellipses in one group that are greater than the standard ellipses in the other group, within $10^{6}$ replicates) and to calculate the occurrence percentage of overlap between ellipses among all model solutions.

Low sample sizes did not allow niche size comparisons for estuarine Guiana dolphins. The beach hunter sample is represented on the $\delta$-space chart but was not included in any statistical analysis because it is just a single sample.

\section{RESULTS}

\section{Stable isotope ratios}

Even with the apparent similarity, the $\delta^{13} \mathrm{C}$ mean value of franciscana dolphins was significantly higher than the coastal Guiana dolphins mean $(W=112 ; p<0.05)$, as well as the average of $\delta^{13} C$ values of estuarine Guiana dolphins when compared to coastal Guiana dolphins values $(\mathrm{t}=-2.24 ; p<0.05)$ (Table I and Figure 2a). Despite the greater variation of the franciscanas' $\delta^{15} \mathrm{~N}$ values (Figure $2 \mathrm{a}$ ), their mean value was not significantly different from the coastal Guiana dolphins value $(t=0.63 ; p=0.53)$, while the $\delta^{15} \mathrm{~N}$ mean value of coastal Guiana dolphins was significantly higher than the estuarine ones $(t=8.19 ; p<0.05)$ (Table I and Figure 2a). The beach hunter dolphin presented $\delta^{13} \mathrm{C}$ values of $-13.9 \%$ and $\delta^{15} \mathrm{~N}$ values of $11.3 \%$.

The averages for franciscana dolphins' females and males were similar for both $\delta^{13} \mathrm{C}$ $(\mathrm{t}=1.46 ; p=0.18)$ and $\delta^{15} \mathrm{~N}$ values $(\mathrm{t}=0.35 ; p=$ 0.73) (Table I and Figure. 2b). The same occurred for coastal Guiana dolphins' females and males: their $\delta^{13} \mathrm{C}(\mathrm{W}=28 ; p=0.13)$ and $\delta^{15} \mathrm{~N}(\mathrm{~W}=26 ; p=$ 0.24 ) values were statistically equal (Table I and Figure 2b).
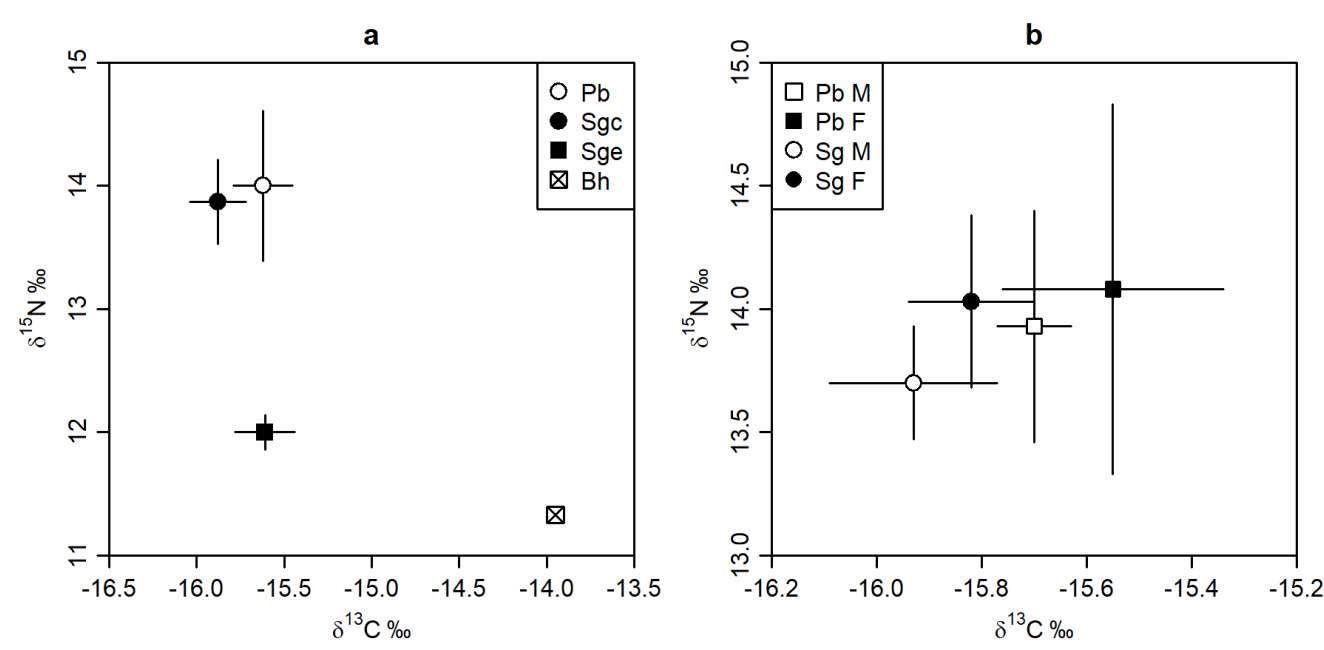

Figure 2. Means
(dots) and standard
deviations
(segments) of $\delta^{13} \mathrm{C}$
and $\delta^{15} \mathrm{~N}$ values
of (1a) sampled
dolphins and their
(1b) sex classes.
Pb: franciscana
dolphin; Sgc: coastal
Guiana dolphin; Sge:
estuarine Guiana
dolphin; Bh: beach
hunter; M: males; F:
females. 


\section{Isotopic niche - Size and overlap}

The isotopic niche size of franciscana sampled was larger when compared with coastal Guiana dolphin (Table I and Figure 3) with a $90 \%$ probability estimated from SEAb. Regarding sex classes, females had larger isotopic niche size than males for both franciscana and Guiana dolphins, with a probability of $98 \%$ and $58 \%$, respectively.

There was a total shared area of $0.04 \%{ }^{2}$ (7\%) between the isotopic niches of franciscana and coastal Guiana dolphins (Table II). Overlap occurred in 56\% of the total Bayesian estimates. For gender comparisons, the total shared area of the isotopic niches (SEAC) of franciscanas' females and males was $0.12 \%{ }^{2}(21 \%)$, but the niche overlap of female over male was much larger than the opposite (Table II). The overlap occurred in $39 \%$ of the model solutions. For Guiana dolphins' sex classes, the total overlap of isotopic niches of females and males was approximately $0.09 \%{ }^{2}$ (28\%) (Table II) and the overlap occurred in $44 \%$ of the total model solutions.

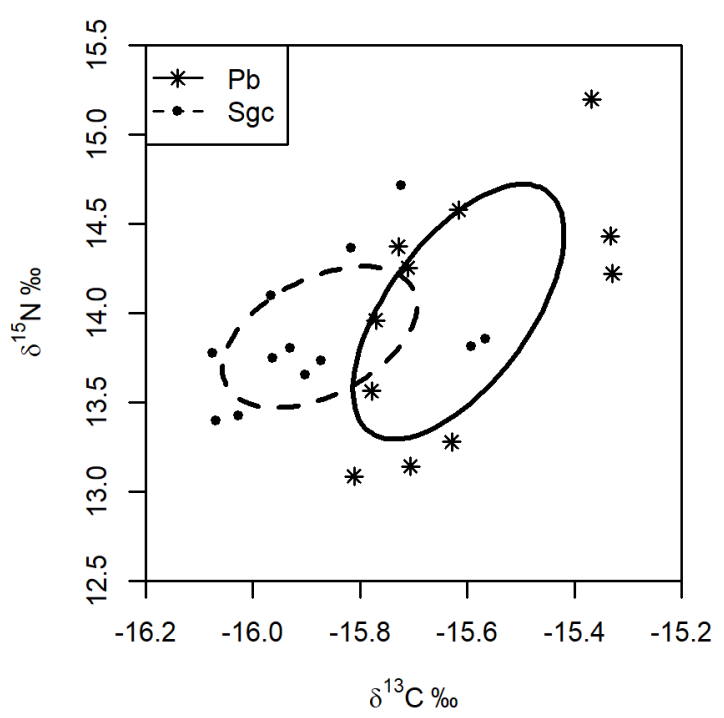

Figure 3. Scatter plot of the $\delta^{13} \mathrm{C}$ and $\delta^{15} \mathrm{~N}$ values ( $\delta$-space) of franciscana dolphins $(\mathrm{Pb})$ and coastal Guiana dolphins (Sgc). Each dot represents an individual and each ellipse represents $40 \%$ of the samples of each species using the SEAC statistic.
Table II. Isotopic $\left(\delta^{13} \mathrm{C}, \delta^{15} \mathrm{~N}\right)$ niche overlap between the standard ellipses corrected for small sample sizes (SEAc) represented in area $\left(\% \mathrm{o}^{2}\right)$ and percentage (\%) unit of sampled Guiana (Sotalia guianensis; Sgc) and franciscana (Pontoporia blainvillei; $\mathrm{Pb}$ ) dolphins in Southeastern Brazil from 2011 to 2018, split by sexual classes (M: male; F: female).

\begin{tabular}{|c|c|c|}
\hline Species / Sex & Overlap $\left(\% \circ^{2}\right)$ & Overlap (\%) \\
\hline \multicolumn{3}{|c|}{ Species } \\
\hline $\mathrm{Pb}$ over Sgc & \multirow{3}{*}{0.04} & 18 \\
\hline Sgc over Pb & & 10 \\
\hline Shared area & & 7 \\
\hline \multicolumn{3}{|c|}{ Sex Pb } \\
\hline M over $F$ & \multirow{3}{*}{0.12} & 23 \\
\hline F over M & & 71 \\
\hline Shared area & & 21 \\
\hline \multicolumn{3}{|c|}{ Sex Sgc } \\
\hline M over $F$ & \multirow{3}{*}{0.09} & 41 \\
\hline F over M & & 46 \\
\hline Shared area & & 28 \\
\hline
\end{tabular}

\section{DISCUSSION}

The $\delta^{13} \mathrm{C}$ and $\delta^{15} \mathrm{~N}$ values found for the franciscana and the Guiana dolphin of the southern coast of the State of São Paulo were consistent and in the same order of magnitude as in previous studies along the southeast and southern coast of Brazil (Di Beneditto et al. 2011, 2016, Bisi et al. 2013, Hardt et al. 2013, Kehrig et al. 2013, Baptista et al. 2016).

Comparing the franciscana and the Guiana dolphin isotopic values in the southern coastal region of the São Paulo State, the present study indicated the occurrence of niche partitioning. The overlap area between the isotopic niches was low (Table II) and this difference occurred mainly due to the $\delta^{13} \mathrm{C}$ values, suggesting spatial segregation between species. The occurrence of niche partitioning has already been recorded in other cetacean species as a way to avoid 
intra and inter-specific competition (Fernández et al. 2011, Giménez et al. 2017). Moreover, the franciscana showed a greater variation of the $\delta^{15} \mathrm{~N}$ values than the Guiana dolphin, which resulted in a larger niche area, indicating greater plasticity of their trophic niche.

A possible explanation for the observed differences of carbon sources assimilated by analyzed franciscanas and Guiana dolphins may be related to preferences on foraging areas. Benthic systems are enriched in ${ }^{13} \mathrm{C}$ compared to pelagic systems (Newsome et al. 2007). The analyzed franciscana dolphins were enriched in ${ }^{13} \mathrm{C}$ compared to Guiana dolphins, which may indicate a greater dependence on benthonic sources in its diet. Although previous literature on stomach content analysis showed that both species preferentially fed on prey with demersal habits along their whole distribution (Danilewicz et al. 2002, Rosas et al. 2010), previous studies in the surveyed area have reported distinct fish species as the main ones for franciscanas (American coastal pellona, Pellona haroweri, and Bigtooth corvina, Isopisthus parvipinnis) and Guiana dolphins (Banded croaker, Paralonchurus brasiliensis, and Atlantic cutlassfish, Trichiurus lepturus) (Lopes et al. 2012, Campos et al. 2020). This difference in prey compositions may have influenced the $\delta^{13} \mathrm{C}$ and $\delta^{15} \mathrm{~N}$ values, as these fish probably have distinct isotopic signatures. To test this hypothesis, a study of the isotopic values of the main prey would be welcome.

Another factor that may be influencing these distinct $\delta^{13} \mathrm{C}$ values is the distribution of each species within the study site. Locations of incidental captures (e.g. Figure 1) of Guiana dolphins were mostly concentrated close to the estuary entrance, while the analyzed franciscanas captures were uniformly distributed along the coast. Thus, a potential preference for the use of the local estuary entrance should be influencing the carbon isotopic values found for the Guiana dolphins. The influence of estuarine waters on $\delta^{13} \mathrm{C}$ values had already been observed in cetaceans from other areas (Lesage et al. 2001, Bisi et al. 2012). Further investigations on area usage of Guiana dolphins in coastal waters may shed light on these observed results.

Previous work carried out with these two species in other regions has not registered significant differences between $\delta^{13} \mathrm{C}$ values. Baptista et al. (2016) and Di Beneditto \& Monteiro (2016) obtained very similar averages of franciscanas' and Guiana dolphins' $\delta^{13} \mathrm{C}$ values in a study on the north coast of Rio de Janeiro, Brazil. The same pattern was observed by Hardt et al. (2013) in the Babitonga Bay estuary in the State of Santa Catarina, Brazil. Possibly, due to the dimensions of the estuary and the size of the mangrove forest in the study area, there may be a strong influence on the carbon isotopic composition of the organisms that have preferences for using areas closer or far from the main estuarine entrances. It would be prudent to conduct a more refined and specific investigation to assess this influence of the local estuary and mangrove forest on the isotopic composition of the biota spatially along the coastline.

The $\delta^{15} \mathrm{~N}$ values showed no significant difference, suggesting that both franciscana and Guiana dolphins belong to the same trophic level. Some difference between the $\delta^{15} \mathrm{~N}$ values was expected since these species feed on prey of different sizes (Santos et al. 2002, Campos et al. 2020), which influences the $\mathrm{N}$ isotopic values (Jennings et al. 2002, Curtis et al. 2017). These results corroborate the information available in other studies. In the Babitonga Bay estuary, Hardt et al. (2013) also did not observe differences in the values of $\delta^{15} \mathrm{~N}$ and inferred that this occurs because they are at the same trophic level. Baptista et al. (2016) and Di Beneditto \& Monteiro (2016) in their studies on 
the north coast of Rio de Janeiro suggested that this similarity occurs due to the variation in the size of the prey and the amount of food eaten, as observed by Lassalle et al. (2014).

Nevertheless, the variation on nitrogen isotopic values was higher for franciscanas (e.g. Figure 2), which resulted in a greater SEAc (Table I). Sampled franciscanas probably fed on prey with a greater diversity of trophic levels, perhaps due to their wider distribution along the coast when compared to the sampled Guiana dolphins. The difference between niche sizes generally suggests a different specialization degree on the species diet (Jackson et al. 2011, Das et al. 2017). As the franciscana showed a larger isotopic niche, it would be more generalist than the Guiana dolphin. However, according to feeding habits studies of these two species throughout their distribution, this would be unlikely, as both were considered generalists (see Cremer et al. 2012, Lopes et al. 2012, Campos et al. 2020). What may be influencing the different niche sizes observed is the intraspecific variability among individuals of the investigated populations, as the populations may be considered as generalists, but are composed of specialist individuals (Bolnick et al. 2003, Bearhop et al. 2004). Nevertheless, in order to better evaluate the habits of these populations, stable isotopic analyses of more than one tissue type should be used (see Bearhop et al. 2004).

Regarding the estuarine and coastal Guiana dolphins, both $\delta^{13} \mathrm{C}$ and $\delta^{15} \mathrm{~N}$ values were significantly different. The estuarine Guiana dolphins were enriched in ${ }^{13} \mathrm{C}$ (Table I). This result may suggest that the carbon basal source within the estuary is more ${ }^{13} \mathrm{C}$ enriched than the coastal one. Interpreting $\delta^{13} \mathrm{C}$ values in estuarine organisms can often be difficult, as a mixture of more than one source (terrestrial, marine pelagic, and marine benthic) usually occurs, resulting in an intermediate value of the sample
(Peterson \& Fry 1987). One way to increase the ability to identify organic matter sources is to simultaneously employ additional tracers such as sulfur isotopes ( $\left.\delta^{34} \mathrm{~S}\right)$ (Peterson \& Fry 1987).

The Guiana dolphin sampled within the estuary presented lower $\delta^{15} \mathrm{~N}$ values than those sampled in the coastal region. Estuaries are generally considered feeding and nurseries areas for the early stages of some fish species (Beck et al. 2001). Younger fish tend to present lower $\delta^{15} \mathrm{~N}$ values when compared to adults (Nagata et al. 2015, Curtis et al. 2017). Thus, Guiana dolphins sampled within the estuary may be feeding on juvenile fish with lower $\delta^{15} \mathrm{~N}$ values. A previous investigation in local waters showed that Guiana dolphins within the estuary fed on smaller prey sizes than the coastal ones (Lopes et al. 2012). Moreover, the main prey of estuarine and coastal Guiana dolphins differed in previous studies, and the coastal Guiana dolphin consumed much more Atlantic cutlassfish (T. lepturus) than the estuarine one (Lopes et al. 2012), which may influence $\delta^{15} \mathrm{~N}$ values, as this fish species can be considered a top predator (high $\delta^{15} \mathrm{~N}$ value) (Di Beneditto et al. 2013). It is important to remember that the estuarine Guiana dolphin sample size is low and may not be representing the wider population, therefore, a future study with larger sample size is needed to verify if trophic and spatial segregation is occurring.

It was observed that the only "beach hunter" sampled in this system had $\delta^{13} \mathrm{C}$ and $\delta^{15} \mathrm{~N}$ values much lower than the other two Guiana dolphin groups. Although conclusions are further limited because it is a single sample, this individual should be more strongly influenced by the estuary isotopic $\delta^{13} \mathrm{C}$ values and should have fed on lower trophic level preys with low $\delta^{15} \mathrm{~N}$ values. Raising the sample size of "beach hunters" will enhance a better interpretation on their preferred prey. 
In this study no significant differences were observed for the mean $\delta^{13} \mathrm{C}$ and $\delta^{15} \mathrm{~N}$ values between franciscana males and females, suggesting a lack of spatial and trophic segregation between the sex classes. Similar results were found in studies of franciscana throughout their distribution (Troina et al. 2016, Paso-Viola et al. 2017). A previous investigation into the franciscana feeding habits in the studied site also indicated this trend (Henning et al. 2018). Furthermore, the similarity between the sex classes of franciscana can also be observed by the high overlap (Table II) of its isotopic niches (Figure 4). This similarity between niches may be associated with the use of similar habitat between females and males of this species, previously reported in Rio Grande do Sul by Danilewicz et al. (2009) analyzing the depths of incidental catches, and by Wells et al. (2013) in a bay in Argentina using telemetry, describing that franciscanas supposedly form pairs of adult males and females for a long time, indicating a monogamy reproductive system.
Few studies have made comparisons between males and females of Guiana dolphins (Pansard et al. 2011, Bisi et al. 2013, Rupil et al. 2018, Rodrigues et al. 2020), most of them have been carried out in the northernmost extent of their distribution in Brazil. In most of them, no differences were observed in feeding habits (Rupil et al. 2018, Rodrigues et al. 2020) and isotopic niches (Bisi et al. 2013) between sex classes. Only Pansard et al. (2011) found a difference between the main food items of Guiana dolphins' males and females on the northeast coast of Brazil. In the present study, no significant differences were observed on the mean $\delta^{13} \mathrm{C}$ and $\delta^{15} \mathrm{~N}$ values, as well as the size of the isotopic niches between sexes of evaluated Guiana dolphins, agreeing with previous studies. Although the small sample size in our study rules out a definite conclusion, this may suggest an absence of segregation between the sex classes for this population.

The present study added new information to the previous knowledge, evidenced regional

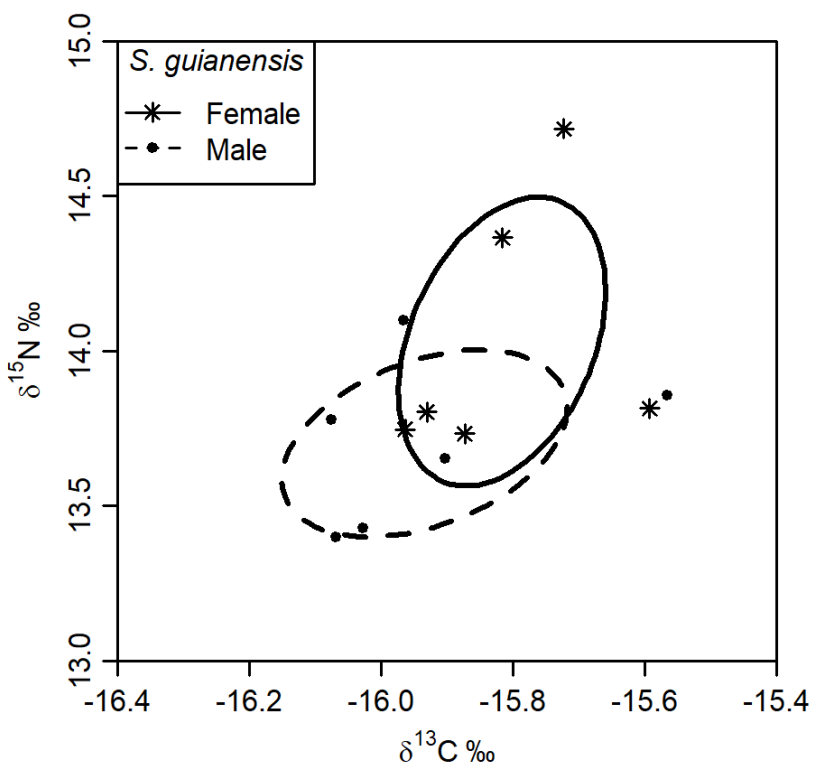

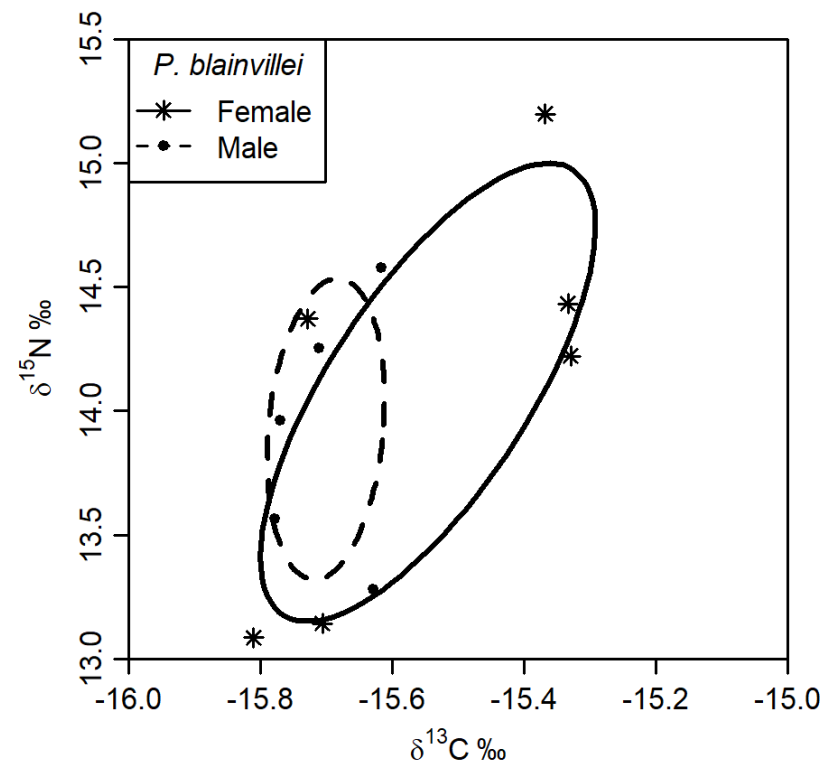

Figure 4. Scatter plot of the $\delta^{13} \mathrm{C}$ and $\delta^{15} \mathrm{~N}$ values ( $\delta$-space) of the sex classes of franciscana dolphins (left) and coastal Guiana dolphins (right). Each dot represents an individual and each ellipse represents $40 \%$ of the samples of each species using the SEAc statistic. 
differences when comparing to previous studies of both species, and indicated new pathways to be investigated. Stable isotopes should be kept in the loop in further studies of local franciscana and Guiana dolphins, with larger sample sizes and adding new markers to improve the preliminary results presented by this study. Despite the small sample size, each piece of information is extremely relevant to increase knowledge about these species and for possible conservation measures.

\section{Acknowledgments}

Logistic support was provided by the Instituto Oceanográfico - Universidade de São Paulo. The authors thank all fishermen who helped by collecting data. Samples were collected under permits SISBIO \#155722 and \#35635. The authors also thank Dr. Raymond Lee, coordinator of the Stable Isotope Core Laboratory at Washington State University (WSU) for doing the samples isotopic analysis and for all the help involved in this process. We thank Genyffer Troina and Victor Uber Pachoalini for helping with the stable isotope methodology and providing important insights on data collection and analysis. The authors are thankful for all the efforts made by both reviewers to address very important comments to improve the original manuscript, and the very kind attention of the associated editor. The following institutions provided financial support to this study: Fundação de Amparo à Pesquisa do Estado de São Paulo (FAPESP process 2010/51323-6; 2011-2015) - “Auxílio Pesquisa - Programa Parceria para Inovação Tecnológica (PITE) - "Capturas acidentais de pequenos cetáceos em atividades pesqueiras no litoral sul paulista: buscando subsídios para formulações de política de conservação". LBC received a Master fellowship from Coordenação de Aperfeiçoamento de Pessoal de Nivel Superior (CAPES/Proex institutional quota; 2017-2019), a Research Grant from Cetacean Society International (CSI), and a Technological Training fellowship from Fundação para o Desenvolvimento Tecnológico da Engenharia (FDTE process number 1700.01.19; 2019). MCOS received a 30-month fellowship from Conselho Nacional de Desenvolvimento Científico e Tecnológico (CNPq process number 308331/2010-9; 2010-2013).

\section{REFERENCES}

ABEND AG \& SMITH TD. 1997. Differences in stable isotope ratios of carbon and nitrogen between long-finned pilot whales (Globicephala melas) and their primary prey in the western north Atlantic. ICES J Mar 54(3): 500-503.

AUBIN DJ ST, SMITH TG \& GERACI JR. 1990. Seasonal epidermal molt in beluga whales, Delphinapterus leucas. Can J of Zool 68(2): 359-367.

BAPTISTA G, KEHRIG HA, DI BENEDITTO APM, HAUSER-DAVIS RA, ALMEIDA MG, REZENDE CE, SICILIANO S, MOURA JF \& MOREIRA I. 2016. Mercury, selenium and stable isotopes in four small cetaceans from the Southeastern Brazilian coast: Influence of feeding strategy. Environ Pollut 218: 1298-1307.

BEARHOP S, ADAMS CE, WALDRONS S, FULLER RA \& MACLEOD H. 2004. Determining trophic niche width: A novel approach using stable isotope analysis. J Anim Ecol 73(5): 1007-1012.

BECK MW ET AL. 2001. The identification, conservation, and management of estuarine and marine nurseries for fish and invertebrates. BioScience 51(8): 633-641.

BISI TL, DORNELES PR, LAILSON-BRITO J, LEPOINT G, AZEVEDO AF, FLACH L, MALM O \& DAS K. 2013. Trophic relationships and habitat preferences of delphinids from the southeastern Brazilian coast determined by carbon and nitrogen stable isotope composition. PLOS ONE 12: 1-8.

BISI TL, LEPOINT G, AZEVEDO AF, DORNELELES PR, FLACH L, DAS K, MALM O \& LAILSON-BRITO J. 2012. Trophic relationships and mercury biomagnification in Brazilian tropical coastal food webs. Ecol Indic 18: 91-302.

BOLNICK DI, SVANBÄCK R, FORDYCE JA, YANG LH, DAVIS JM, HULSEY CD \& FORISTER ML. 2003. The Ecology of Individuals: Incidence and Implications of Individual Specialization. Am Nat 161(1): 1-28.

BORDINO P, SICILIANO S, BASTIDA R \& CREMER M. 2002. Report of the working group on distribution and behavior. Lat Am J Aquat Mamm 1(1): 21-23.

CAMPOS LB, LOPES XM, SILVA E \& SANTOS MCO. 2020. Feeding habits of the franciscana dolphin (Pontoporia blainvillei) in southeastern Brazil. J Mar Biol Assoc UK 100(2): 301-313.

CLARKE MR. 1986. Cephalopods in the diet of odontocetes. In Bryden MM \& Harrison R (Eds), Research on Dolphins, Oxford: Claredon Press, p. 281-321.

CREMER MJ, PINHEIRO PC \& SIMÕES-LOPES PC. 2012. Prey consumed by Guiana dolphin Sotalia guianensis (Cetacea, Delphinidae) and franciscana dolphin Pontoporia blainvillei (Cetacea, Pontoporiidae) in an 
estuarine environment in southern Brazil. Iheringia Ser Zool 102(2): 131-137.

CRESPO EA ET AL. 2010. Report of the working group on major threats and conservation. Lat Am J Aquat Mamm 8(1-2): 47-56.

CURTIS JS, WALL KR, ALBINS MA \& STALLINGS CD. 2017. Diet shifts in a native mesopredator across a range of invasive lionfish biomass. Mar Ecol Prog Ser 573: 215-228.

DANILEWICZ DS ET AL. 2002. Report of the working group on biology and ecology. Lat Am J Aquat Mamm 1(1): 25-42.

DAS K, HOLLEVILLE O, RYAN C, BERROW S, GILLES A, ODY D \& MICHEL LN. 2017. Isotopic niches of fin whales from the Mediterranean Sea and the Celtic Sea (North Atlantic). Mar Environ Res 127: 75-83.

DAURA-JORGE FG, WEDEKIN LL \& SIMÕES-LOPES PC. 2011. Feeding habits of the Guiana dolphin, Sotalia guianensis (Cetacea: Delphinidae), in Norte Bay, southern Brazil. Sci Mar 75(1): 163-169.

DENIRO MJ \& EPSTEIN S. 1978. Influence of diet on the distribution of carbon isotopes in animals. Geochim et Cosmochim Ac 42(5): 495-506.

DENIRO MJ \& EPSTEIN S. 1981. Influence of diet on the distribution of nitrogen isotopes in animals. Geochim et Cosmochim Ac 45(3): 341-351.

DI BENEDITTO APM \& MONTEIRO LR. 2016 Isotopic niche of two coastal dolphins in a tropical marine area: specific and age class comparisons. J Mar Biol Assoc UK 96(4): 853-858.

DI BENEDITTO APM \& RAMOS S. 2001. Biology and conservation of the franciscana (Pontoporia blainvillei) in the north of Rio de Janeiro State, Brazil. J Cetacean Res Manag 3(2): 185-192.

DI BENEDITTO APM, REZENDE CE, CAMARGO PB \& KEHRIG HA. 2013. Trophic niche comparison between two predators in northern Rio de Janeiro State, Brazil: a stable isotopes approach Trophic niche comparison between two predators in northern Rio de Janeiro State, Brazil: a stable isotopes approach. Biota Neotrop 13(3): 0-5.

DI BENEDITTO APM \& SICILIANO S. 2007. Stomach contents of the marine tucuxi dolphin (Sotalia guianensis) from Rio de Janeiro, south-eastern Brazil. J Mar Biol Assoc UK 87(1): 253-254.

DI BENEDITTO APM, SOUZA CMM, KEHRIG HA \& REZENDE CE. 2011. Use of multiple tools to assess the feeding preference of coastal dolphins. Mar Biol 158(10): 2209-2217.

FERNÁNDEZ R, GARCÍA-TISCAR S, SANTOS MB, LÓPEZ A, MARTÍNEZCEDEIRA JÁ, NEWTON J \& PIERCE GJ. 2011. Stable isotope analysis in two sympatric populations of bottlenose dolphins Tursiops truncatus: Evidence of resource partitioning? Mar Biol 158(5): 1043-1055.

FITCH JE \& BROWNELL RL. 1968. Fish otoliths in cetacean stomachs and their importance in interpreting feeding habits. J Fish Res Board Can 25(12): 2561-2574.

FORCADA J. 2018. Distribution. In Würsig B, Thewissen JGM \& Kovacs KM (Eds), Encyclopedia of Marine Mammals. $3^{\text {rd }}$ Ed., London, UK: Academic Press, p. 259-262.

GAUSE GF. 2003. The Struggle for Existence: A Classic of Mathematical Biology and Ecology. New York: Dover Publications. Reprint, p. 163.

GIMÉNEZ J, CAÑADAS A, RAMÍREZ F, AFÁN I, GARCÍA-TISCAR S, FERNÁNDEZ-MALDONADO C, CASTILLO JJ \& STEPHANIS R. 2017. Intra-and interspecific niche partitioning in striped and common dolphins inhabiting the southwestern Mediterranean Sea. Mar Ecol Prog Ser 567: 199-210.

GIMÉNEZ J, RAMÍREZ F, ALMUNIA J, FORERO MG \& STEPHANIS R. 2016. From the pool to the sea: Applicable isotope turnover rates and diet to skin discrimination factors for bottlenose dolphins (Tursiops truncatus). J Exp Mar Biol Ecol 475: 54-61.

HARDT FAS, CREMER MJ, JUNIOR AJT, BELLANTE A, BUFFA G, BUSCAINO G, MAZZOLA S, BARRETO AS, MARTINELLI LA \& ZUPPI GM. 2013. Use of carbon and nitrogen stable isotopes to study the feeding ecology of small coastal cetacean populations in southern Brazil. Biota Neotrop 13(4): 90-98.

HENNING B, CARVALHO BS, PIRES MM, BASSOI M, MARIGO J, BERTOZZI C \& ARAÚJO MS. 2018. Geographical and intrapopulation variation in the diet of a threatened marine predator, Pontoporia blainvillei (Cetacea). Biotropica 50(1): 157-168.

HOBSON KA, SCHELL DM, RENOUF D \& NOSEWORTHY E. 1996. Stable carbon and nitrogen isotopic fractionation between diet and tissues of captive seals: implications for dietary reconstructions involving marine mammals. Can J Fish Aquat Sci 53(3): 528-533.

HUTCHINSON GE. 1957. Concluding Remarks. Cold Spring Harb Symp Quant Biol 22: 415-427.

JACKSON AL, INGER R, PERNELL AC \& BEARHOP S. 2011. Comparing isotopic niche widths among and within communities: SIBER - Stable Isotope Bayesian Ellipses in R. J Anim Ecol 80(3): 595-602.

JENNINGS S, PINNEGAR JK, NICHOLAS VC \& WARR KJ. 2002. Linking size-based and trophic analyses of benthic community structure. Mar Ecol Prog Ser 226: 77-85. 
KEHRIG HA, SEIXAS TG, MALM O, DI BENEDITTO APM \& REZENDE CE. 2013. Mercury and selenium biomagnification in a Brazilian coastal food web using nitrogen stable isotope analysis: a case study in an area under the influence of the Paraiba do Sul River plume. Mar Pollut Bull 75(1-2): 283-290.

KELLY JF. 2000. Stable isotopes of carbon and nitrogen in the study of avian and mammalian trophic ecology. Can J Zool 78(1): 1-27.

KISZKA J, OREMUS M, RICHARD P, POOLE M \& RIDOUX V. 2010. The use of stable isotope analyses from skin biopsy samples to assess trophic relationships of sympatric delphinids off Moorea (French Polynesia). J Exp Mar Biol Ecol 395(1-2): 48-54.

LASSALLE G, CHOUVELON T, BUSTANAMANTE P \& NIQUIL N. 2014. An assessment of the trophic structure of the Bay of Biscay continental shelf food web: Comparing estimates derived from an ecosystem model and isotopic data. Prog in Oceanogr 120: 205-215.

LESAGE V, HAMMILL MO \& KOVACS KM. 2001. Marine mammals and the community structure of the Estuary and Gulf of St Lawrence, Canada: Evidence from stable isotope analysis. Mar Ecol Prog Ser 210: 203-221.

LESAGE V, MORIN Y, RIOUX Ė, PORMERLAU C, FERGUSON SH \& PELLETIER E. 2010. Stable isotopes and trace elements as indicators of diet and habitat use in cetaceans: Predicting errors related to preservation, lipid extraction, and lipid normalization. Mar Ecol Prog Ser 419: 249-265.

LOPES XM, SILVA E, BASSOI M, SANTOS RA \& SANTOS MCO. 2012. Feeding habits of Guiana dolphins, Sotalia guianensis, from south-eastern Brazil: new items and a knowledge review. J Mar Biol Assoc UK 92(8): 1723-1733.

MCCONNAUGHEY T \& MCROY CP. 1979. Food-Web structure and the fractionation of Carbon isotopes in the Bering sea. Mar Biol 53(3): 257-262.

MINAGAWA M \& WADA E. 1984. Stepwise enrichment of $15 \mathrm{~N}$ along food chains Further evidence and the relation between d15N and animal age. Geochim et Cosmochim Ac 48(5): 1135-1140.

MOORE SE. 2008. Marine mammals as ecosystem sentinels. J Mammal 89(3): 534-540.

NAGATA RM, MOREIRA MZ, PIMENTEL CR \& MORANDINI AC. 2015. Food web characterization based on $\delta 15 \mathrm{~N}$ and $\delta 13 \mathrm{C}$ reveals isotopic niche partitioning between fish and jellyfish in a relatively pristine ecosystem. Mar Ecol Prog Ser 519: 13-27.
NEWSOME SD, CLEMENTZ MT \& KOCH PL. 2010. Using stable isotope biogeochemistry to study marine mammal ecology. Mar Mamm Sci 26(3): 509-572.

NEWSOME SD, DEL RIO CM, BEARHOP S \& PHILLIPS DL. 2007. A niche for isotopic ecology. Front Ecol Environ 5(8): 429-436.

OTT PH ET AL. 2002. Report of the working group on fishery interactions. Lat Am J Aquat Mamm 1(1): 55-64.

PANSARD KCA, GURGEL HCB, ANDRADE LCA \& YAMAMOTO ME. 2011. Feeding ecology of the estuarine dolphin (Sotalia guianensis) on the coast of Rio Grande do Norte, Brazil. Mar Mamm Sci 27(4): 673-687.

PASO-VIOLA, MN, RICCIALDELLI L, NEGRI MF, PANEBIANCO MV, PANARELLO HO \& CAPPOZZO HL. 2017. Intra-specific isotope variations of franciscana dolphin Pontoporia blainvillei regarding biological parameters and distinct environments. Mamm Biol 85(1): 47-54

PETERSON BJ \& FRY B. 1987. Stable Isotopes in Ecosystem Studies. Annu Rev Ecol Syst 18: 293-320.

PIANKA ER. 1974. Niche overlap and diffuse competition. P Natl Acad Sci USA 71(5): 2141-2145.

PINNEGAR JK \& POLUNIN NVC. 1999. Differential fractionation of $\delta 13 \mathrm{C}$ and $\delta 15 \mathrm{~N}$ among fish tissues: implications for the study of trophic interactions. Funct Ecol 13(2): 225-231.

R CORE TEAM. 2018. R: A language and environment for statistical computing. R Foundation for Statistical Computing, Vienna, Austria.

RODRIGUES VLA, WEDEKIN LL, MARCONDES MCC, BARBOSA L \& FARRO APC. 2020. Diet and foraging opportunism of the Guiana dolphin (Sotalia guianensis) in the Abrolhos Bank, Brazil. Mar Mamm Sci 36(2): 436-450.

RODRÍGUEZ D, RIVERO L \& BASTIDA R. 2002. Feeding ecology of the franciscana (Pontoporia blainvillei) in marine and estuarine waters of Argentina. Lat Am J Aquat Mamm 1(1): 77-94.

ROSAS FCW, MARIGO J, LAETA M \& ROSSI-SANTOS MR. 2010. Natural history of dolphins of the genus Sotalia. Lat Am J Aquat Mamm 8(1-2): 57-68.

RUPIL GM, BOGONI JA, BARBOSA L, MARCONDES MCM \& FARRO APC. 2018. Climate influences on Guiana dolphin diet along the Brazilian coast. Sci Mar 82(3): 159-168.

SANTOS MCO, LAILSON-BRITO J, FLACH L, OSHIMA JEF, FIGUEIREDO GC, CARVALHO RR, VENTURA ES, MOLINA JMB \& AZEVEDO AF. 2019. Cetacean movements in coastal waters of the southwestern Atlantic ocean. Biota Neotrop 19(2): e20180670. 
SANTOS MCO, PACÍFICO ES \& GONÇALVES MF. 2007. Unusual record of franciscana dolphins (Pontoporia blainvillei) in inner waters of the Cananéia estuary, southeastern Brazil. Lat Am J Aquat Mamm 6(1): 117-119.

SANTOS MCO, ROSSO S, SANTOS RA, LUCATO SHB \& BASSOI M. 2002. Insights on small cetacean feeding habits in southeastern Brazil. Aquat Mamm 28(1): 38-45.

SANTOS MCO, SICILIANO S, VICENTE AFC, ALVARENGA FS, ZAMPIROLLI E, SOUZA SP \& MARANHO A. 2010. Cetacean records along São Paulo State coast, southeastern Brazil. Braz J Oceanogr 58(2): 123-142.

SCHOENER TW. 1974. Resource partitioning in ecological communities. Science 185(4145): 27-39.

SECCHI ER, SANTOS MCO \& REEVES R. 2018. Sotalia guianensis (errata version published in 2019), The IUCN Red List of Threatened Species 2018: e.T181359A144232542. Available at: http://dx.doi.org/10.2305/IUCN.UK.2018-2.RLTS. T181359A50386256.en. (Accessed: 22 March 2019).

SILVA VMF ET AL. 2010. Report of the working group on distribution, habitat characteristics and preferences, and group size. Lat Am J Aquat Mamm 8(1-2): 31-38.

TAYLOR WP. 1924. The basic importance of life history studies. J Mammal 5(1): 44-48.

TIESZEN LL, BOUTTON TW, TESDAHL KG \& SLADE NA. 1983. Fractionation and turnover of stable carbon isotopes in animal tissues: Implications for $813 \mathrm{C}$ analysis of diet. Oecologia 57(1-2): 32-37.

TRITES AW \& SPITZ J. 2018. Diet. In Würsig B, Thewiseen JGM \& Kovacs KM (Eds), Encyclopedia of Marine Mammals. 3rd ed., London, UK: Academic Press, p. 255-259.

TROINA G, BOTTA S, SECCHI ER \& DEHAIRS F. 2016. Ontogenetic and sexual characterization of the feeding habits of franciscanas, Pontoporia blainvillei, based on tooth dentin carbon and nitrogen stable isotopes. Mar Mamm Sci 32(3): 1115-1137.

WELLS RS, BORDINO P \& DOUGLAS DC. 2013. Patterns of social association in the franciscana, Pontoporia blainvillei. Mar Mamm Sci 29(4): E520-E528.

ZERBINI AN, SECCHI E, CRESPO E, DANILEWICZ D \& REEVES R. 2017. Pontoporia blainvillei (errata version published in 2018), The IUCN Red List of Threatened Species 2017: e.T17978A123792204. Available at: http://dx.doi. org/10.2305/IUCN.UK.2017-3.RLTS.T17978A50371075.en (Accessed: 17 March 2019).

\section{How to cite}

CAMPOS LB \& SANTOS MCO. 2021. Trophic relationships and use of area of two sympatric small cetaceans in the Southwestern Atlantic Ocean determined by carbon and nitrogen stable isotopes. An Acad Bras Cienc 93: e20200638. DOI 10.1590/0001-3765202120200638.

Manuscript received on April 27, 2020;

accepted for publication on August 7, 2020

\section{LAURA B. CAMPOS}

https://orcid.org/0000-0003-0541-6139

\section{MARCOS CÉSAR DE O. SANTOS}

https://orcid.org/0000-0002-6642-2658

Laboratório de Biologia da Conservação de Mamíferos Aquáticos (LABCMA), Departamento de Oceanografia Biológica, Instituto Oceanográfico da Universidade de São Paulo (USP), Praça do Oceanográfico, 191, Cidade Universitária, Butantã, 05508-120 São Paulo, SP, Brazil

Correspondence to: Laura B. Campos

E-mail:laurabusincampos@gmail.com

\section{Author contributions}

All authors played an important role in the construction of this manuscript. LBC prepared the samples for analysis, performed the statistical analysis and data interpretation, prepared the tables and figures, and wrote the final manuscript. MCOS was the academic advisor and was responsible for collecting part of the data, obtaining funds, and managing the project, reviewing and correcting the final manuscript.

\section{(c) BY}

